\title{
PENGARUH KINERJA LINGKUNGAN, BIAYA LINGKUNGAN, DAN UKURAN PERUSAHAAN TERHADAP KINERJA KEUANGAN DENGAN CORPORATE SOCIAL RESPONSIBILITY SEBAGAI VARIABEL INTERVENING
}

(Studi Empiris Pada Perusahaan Manufaktur yang Terdaftar di Bursa Efek Indonesia Tahun 2014-2016)

\author{
Aida Meiyana \\ Program Studi Akuntansi Fakultas Ekonomi Universitas Negeri Yogyakarta \\ aidameiyana@gmail.com \\ Mimin Nur Aisyah, M.Sc., Ak. \\ Staf Pengajar Program Studi Akuntansi Universitas Negeri Yogyakarta \\ mimin_nuraisyah@uny.ac.id
}

\begin{abstract}
Abstrak : Pengaruh Kinerja Lingkungan, Biaya Lingkungan, Dan Ukuran Perusahaan Terhadap Kinerja Keuangan Dengan Corporate Social Responsibility Sebagai Variabel Intervening. Penelitian ini bertujuan untuk mengetahui (1) pengaruh kinerja lingkungan terhadap kinerja keuangan, (2) pengaruh biaya lingkungan terhadap kinerja keuangan, (3) pengaruh ukuran perusahaan terhadap kinerja keuangan, (4) pengaruh Corporate Social Responsibility (CSR) terhadap kinerja keuangan, (5) CSR sebagai mediator dalam pengaruh kinerja lingkungan terhadap kinerja keuangan, (6) CSR sebagai mediator dalam pengaruh biaya lingkungan terhadap kinerja keuangan, dan (7) CSR sebagai mediator dalam pengaruh ukuran perusahaan terhadap kinerja keuangan. Penelitian ini termasuk dalam penelitian kausal komparatif. Populasi penelitian ini adalah perusahaan manufaktur yang terdaftar di Bursa Efek Indonesia Tahun 2014-2016. Dengan menggunakan metode purposive sampling, terdapat 39 perusahaan yang memenuhi kriteria dengan total 97 data set. Teknik analisis data yang digunakan adalah analisis regresi linier sederhana, analisis jalur, dan uji Sobel. Hasil penelitian ini menunjukkan bahwa (1) kinerja lingkungan tidak berpengaruh terhadap kinerja keuangan, (2) biaya lingkungan berpengaruh negatif terhadap kinerja keuangan, (3) ukuran perusahaan berpengaruh positif terhadap kinerja keuangan, (4) CSR berpengaruh positif terhadap kinerja keuangan, (5) CSR mampu memediasi pengaruh kinerja lingkungan terhadap kinerja keuangan, (6) CSR tidak mampu memediasi hubungan biaya lingkungan terhadap kinerja keuangan, dan (7) CSR mampu memediasi pengaruh ukuran perusahaan terhadap kinerja keuangan
\end{abstract}

Kata kunci: kinerja keuangan, kinerja lingkungan, biaya lingkungan, ukuran perusahaan, Corporate Social Responsibility

Abstract: The Influence Of Environmental Performance, Environmental Cost, And Company Size On The Financial Performance With Corporate Social Responsibility As Intervening Variable (An Emperial Study On Manufacturing Companies Listed In Bursa Efek Indonesia In The Period Of 20142016. This study aims at analyzing (1) influence of environmental performance on the financial performance, (2) influence of environmental cost on the financial performance, (3) the influence of company size on the financial performance, (4) influence of Corporate Social Responsibility (CSR) on the financial performance, (5) CSR as mediator on influence of environmental performance towards the financial performance, (6) CSR as mediator on influence of environmental cost towards the financial performance, and (7) CSR as mediator on influence of company size towards the financial performance. This study was a causal comparative research. The population of this research were manufacturing companies listed in Bursa Efek Indonesia in the period of 2014-2016. Using a purposive sampling method there were 39 companies as samples and 97 data set were obtained. The data analysis techniques used were simple linier regression analysis, path analysis, and Sobel test. The results of this research indicate that (1) environmental performance is not able to influence the financial performance, (2) environmental cost negatively influences the financial performance, (3) company size positively influences the financial performance, (4) CSR positively influences the financial performance, (5) CSR 


\section{JURNAL NOMINAL / VOLUME VIII NOMOR 1 / TAHUN 2019}

mediates the effect of environmental performance on the financial performance, (6) CSR is not able to mediate the effect of environmental cost on the financial performance, and (7) CSR mediates the effect of company size on the financial performance.

Keywords: financial performance, environmental performance, environmental cost, company size, Corporate Social Responsibility

PENDAHULUAN

Salah satu cara untuk menilai kinerja sebuah perusahaan adalah dengan melihat dari kinerja keuangan perusahaannya. Kinerja keuangan menggambarkan bagaimana kegiatan bisnis suatu perusahaan dijalankan serta apa yang sudah dicapai dari kegiatan bisnis tersebut. Pencapaian kegiatan bisnis perusahaan ini digambarkan dengan menghasilkan laba. Hal ini sesuai pendapat Pujiasih (2013) yaitu kemampuan suatu perusahaan dalam menghasilkan laba merupakan hal yang utama dalam penilaian kinerja keuangan perusahaan. Penggunaan laba sebagai parameter dalam mengukur kinerja keuangan ini didasarkan karena laba sangat diperlukan oleh suatu perusahaan untuk kelangsungan hidup perusahaannya (Jayati, 2012).

$$
\text { Kinerja keuangan yang }
$$
digambarkan dengan laba ini juga sebagai indikator pengukuran keberhasilan perusahaan dari segi finansial. Dengan adanya indikator pengukuran tersebut perusahaan dapat melakukan review dan evaluasi, sehingga perusahaan dapat melihat prospek perusahaannya di periode selanjutnya dan juga sebagai upaya mempertahankan

keberlanjutan perusahaan. Dengan demikian kinerja keuangan juga sebagai penentu hidupnya suatu perusahaan. Hal ini dikarenakan dapat berjalannya proses bisnis perusahaan juga membutuhkan sokongan keuangan bagi perusahaan. Oleh karena itu, bisa dikatakan bahwa kinerja keuangan adalah salah satu bentuk tanggung jawab dari perusahaan.

Kinerja keuangan biasa digunakan para investor sebagai tolok ukur. Investor akan menganalisis kinerja keuangan perusahaan dalam pengambilan keputusan investasi. Saat melakukan analisis kinerja keuangan akan dibandingkan periode saat ini dengan periode sebelumnya. Jika dari hasil analisis menunjukkan kinerja keuangan perusahaan baik maka akan menarik para investor dalam menanamkan modalnya. Oleh karena itu, kinerja keuangan juga merupakan hal penting bagi perusahaan untuk mendapatkan asupan modal.

Namun sayangnya, atas dasar ingin menghasilkan laba yang maksimal dan memperoleh asupan modal, sebagian perusahaan masih mengabaikan dampak lingkungan sekitar dan dampak sosial dari 


\section{JURNAL NOMINAL / VOLUME VIII NOMOR 1 / TAHUN 2019}

proses kegiatannya. Hal ini sesuai pendapat Hastawati \& Sarsiti (2016) bahwa prinsip maksimalisasi laba untuk mencari keuntungan maksimal banyak dilanggar perusahaan, seperti rendahnya manajemen lingkungan, kinerja lingkungan, dan rendahnya akan minat terhadap konservasi lingkungan.

Masyarakat kini juga menyadari dampak sosial dari perusahaan yang ingin mencapai laba maksimal, maka masyarakat menuntut agar perusahaan memperhatikan dan mengatasi dampak sosial yang ditimbulkan (Rahmawati, 2012). Saat ini tanggung jawab perusahaan tidak hanya terbatas pada kinerja keuangan namun juga tanggung jawab sosial. Hal ini juga sesuai dengan Peraturan Pemerintah Republik Indonesia Nomor 47 Tahun 2012 tentang Tanggung Jawab Sosial dan Lingkungan Perseroan Terbatas. Tanggung jawab sosial ini sering disebut juga Corporate Social Responsibility yaitu sebagai bentuk tanggung jawab perusahaan baik ke dalam yang diarahkan kepada pemegang saham dan karyawan dalam wujud profitabilitas dan kemajuan perusahaan, maupun tanggung jawab ke luar yang dikaitkan sebagai pembayar pajak dan penyedia lapangan kerja, meningkatkan kesejahteraan dan kompetensi masyarakat, serta memelihara lingkungan bagi generasi mendatang (Susanto, 2009: 11-12).
Corporate Social Responsibility berkaitan erat dengan stakeholder, yaitu semua pihak baik internal maupun eksternal yang memiliki hubungan baik bersifat mempengaruhi maupun dipengaruhi, bersifat langsung maupun tidak langsung oleh perusahaan (Hadi, 2011: 93). Sebagai pihak yang memiliki kepentingan dan tujuan, stakeholder dalam mengambil keputusan juga mempertimbangkan Corporate Social Responsibility yang dijalankan oleh suatu perusahaan. Angela (2015) mengungkapkan transparansi pengungkapan CSR dalam laporan keuangan menjadi penting bagi pemakai laporan keuangan atau stakeholder untuk menganalisis sejauh mana perhatian dan tanggung jawab perusahaan dalam menjalankan bisnis.

Perusahaan yang menjalankan Corporate Social Responsibility dengan baik akan memiliki citra yang baik pula di mata masyarakat. Citra perusahaan yang baik diharapkan memberikan stakeholder good news atau sinyal dalam pengambilan keputusan yang dapat menguntungkan bagi perusahaan. Hal ini sesuai pendapat Angela (2015) yaitu dengan melaksanakan CSR, citra perusahaan akan semakin baik sehingga loyalitas konsumen dan para stakeholder makin tinggi. Sebaliknya jika tingkat pengungkapan CSR ini rendah, maka akan menghambat perusahaan dalam hal memperoleh kepercayaan dari investor 


\section{JURNAL NOMINAL / VOLUME VIII NOMOR 1 / TAHUN 2019}

karena CSR menjadi salah satu hal yang diperhatikan investor ketika akan berinvestasi di sebuah perusahaan (Fajriana, 2016).

Pengelolaan lingkungan sebagai bentuk kontribusi perusahaan kini juga menjadi bahasan penting. Terlebih bagi perusahaan yang bergerak di bidang manufaktur. Tak bisa dipungkiri bahwa proses produksi dari perusahaan manufaktur akan meninggalkan limbah. Jika limbah tersebut tidak diolah sedemikian rupa maka kontribusi perusahaan pada lingkungan adalah dengan melakukan pencemaran.

Perusahaan di Indonesia yang sempat melakukan pencemaran antara lain PT Lapindo Brantas dan PT Newmont Minahasa Raya. Kegiatan pengeboran oleh PT Lapindo yang menyebabkan tidak stabilnya kondisi tanah di bawah lokasi awal yang berakibat pada menyemburnya lumpur dan diperparah dengan terjadinya semburan gas metana disertai air bercampur lumpur. PT Newmont Minahasa Raya juga pernah melakukan pencemaran lingkungan di Teluk Buyat, Kabupaten Bolaang Mongondow, Sulawesi Utara. Tim Ahli dari Universitas Sam Ratulangi menyatakan Newmont terbukti membuang tailing yang mengandung bahan beracun berbahaya (B3) di Teluk Buyat dengan konsentrasi merkuri dan arsenik dalam air laut yang telah melampaui ambang batas baku mutu.

Perusahaan yang melakukan pencemaran dipandang tidak memiliki kinerja lingkungan yang baik. Padahal kinerja lingkungan yang baik bisa mengindikasikan bahwa perusahaan dapat diandalkan dan bisa memberikan kepercayaan pada stakeholder. Dengan adanya informasi mengenai kinerja lingkungan perusahaan akan mengungkapkan seberapa besar usaha perusahaan dalam melaksanakan tanggung jawabnya untuk mengatasi dampak lingkungan yang ditimbulkan.

Untuk menilai kinerja lingkungan perusahaan, pemerintah melalui Kementrian Lingkungan Hidup sejak 2002 membentuk Program Penilaian Peringkat Kinerja Perusahaan dalam Pengelolaan Lingkungan Hidup (PROPER). Program ini merupakan salah satu upaya untuk mendorong penataan perusahaan dalam pengelolaan lingkungan hidup melalui instrumen informasi. Peringkat dibagi menjadi 5 peringkat warna yaitu mulai dari yang terbaik emas, hijau, biru, merah, hingga yang terburuk hitam. Dengan adanya PROPER masyarakat bisa menilai perusahaan mana yang memiliki reputasi baik dalam pengelolaan lingkungan hidup dan mana perusahaan yang reputasinya kurang baik dalam pengelolaan lingkungan. 


\section{JURNAL NOMINAL / VOLUME VIII NOMOR 1 / TAHUN 2019}

Namun sayangnya 13 tahun PROPER berjalan belum sepenuhnya hasil yang diperoleh seperti yang diharapkan. Hal ini dikarenakan masih adanya perusahaan yang mendapat kategori warna merah dan hitam. Hasil PROPER pada periode penilaian tahun 2014-2015 berjumlah 2137 perusahaan dengan 61 perusahaan tidak diumumkan peringkatnya. Untuk rincian peringkat yaitu peringkat emas berjumlah 12 perusahaan $(0,6 \%)$, peringkat hijau sebanyak 108 perusahaan (5,2\%), peringkat biru terdapat 1406 perusahaan $(67,7 \%)$, peringkat merah 529 perusahaan $(25,5 \%)$, dan peringkat hitam sebanyak 21 perusahaan $(1,0 \%)$.

Masih adanya perusahaan yang memperoleh peringkat hitam dan merah cukup mengecewakan, hal ini dikarenakan perusahaan belum melakukan pengelolaan lingkungan sesuai perundang-undangan bahkan secara sengaja tidak melakukan upaya pengelolaan lingkungan sebagaimana yang dipersyaratkan. Padahal menurut Rahmawati (2012) pengelolaan lingkungan yang baik dapat menghindari klaim masyarakat dan pemerintah serta meningkatkan kualitas produk yang akhirnya akan dapat meningkatkan keuntungan finansial perusahaan.

Saat melakukan pengelolaan lingkungan untuk mengatasi dampak yang ditimbulkan tentu perusahaan akan mengalokasikan biaya lingkungan. Namun sayangnya, perusahaan menganggap bahwa biaya lingkungan ini hanyalah menjadi tambahan pengeluaran dana bagi perusahaan. Di sisi lain perusahaan menganggap bahwa biaya lingkungan hanya akan menjadi akun pengurang laba bagi perusahaan. Padahal adanya alokasi biaya untuk pengelolaan lingkungan menunjukkan konsistensi kepedulian lingkungan yang dilakukan perusahaan sehingga membangun kepercayaan masyarakat akan tanggung jawab sosial perusahaan (Tunggal \& Fachrurrozie, 2014). Biaya lingkungan ini bisa dikatakan sebagai investasi jangka panjang, karena dana yang dikeluarkan saat ini bisa memberikan nama baik bagi perusahaan, sehingga bisa menambah kepercayaan stakeholder pada perusahaan.

Stakeholder ataupun investor dalam melakukan keputusan investasi terkadang juga melihat dari total aset yang dimiliki perusahaan atau sering disebut dengan ukuran perusahaan. Perusahaan dengan ukuran besar memiliki akses lebih untuk mendapat sumber pendanaan dari luar, karena dikatakan bahwa perusahaan dengan ukuran besar memiliki kesempatan lebih besar untuk memenangkan persaingan atau bertahan dalam industri (Sugiono \& Christiawan, 2013). Dengan demikian, investor akan mempertimbangkan untuk menanamkan modalnya di perusahaan dengan ukuran besar. 


\section{JURNAL NOMINAL / VOLUME VIII NOMOR 1 / TAHUN 2019}

Berdasarkan uraian latar belakang permasalahan di atas maka peneliti akan membuat penelitian dengan judul "Pengaruh Kinerja Lingkungan, Biaya Lingkungan, dan Ukuran Perusahaan Terhadap Kinerja Keuangan dengan Corporate Social Responsibility Sebagai Variabel Intervening". Penelitian ini dilakukan pada perusahaan manufaktur yang terdaftar di Bursa Efek Indonesia tahun 2014-2016.

\section{METODE PENELITIAN}

\section{Jenis Penelitian}

Penelitian ini menggunakan pendekatan kuantitatif. Menurut Sugiyono (2011: 14) penelitian kuantitatif adalah penelitian dengan memperoleh data yang berbentuk angka atau data kualitatif yang diangkakan.

\section{Waktu dan Tempat Penelitian}

Penelitian ini dilakukan dengan mengambil data di website resmi Bursa Efek Indonesia yaitu http://www.idx.co.id dan website masing-masing perusahaan, serta situs remi dari Kementrian Lingkungan Hidup yaitu http://proper.menlhk.go.id. Pengambilan data dilakukan pada bulan Maret 2018.

\section{Target/Subjek Penelitian}

Populasi dalam penelitian ini adalah perusahaan manufakur yang menjadi anggota di Bursa Efek Indonesia yaitu sebanyak 154 perusahaan.
Kriteria sampel dalam penelitian ini adalah Perusahaan yang menerbitkan laporan keuangan dan laporan tahunan, melaporkan Corporate Social Responsibility, mengikuti program PROPER, menginformasikan biaya terkait kegiatan Corporate Social Responsibility, serta perusahaan yang mengalami laba selama periode tahun 2014, 2015, dan 2016. Adapun perusahaan yang memenuhi kriteria di atas sebanyak 39 perusahaan.

\section{Prosedur}

Teknik pengumpulan data dalam penelitian ini adalah menggunakan metode dokumentasi yaitu cara mengumpulkan data melalui peninggalan yang tertulis seperti arsip dan buku mengenai pendapat, teori atau hukum yang berhubungan dengan masalah penelitian (Margono, 1997: 187). Metode dokumentasi dilakukan dengan mengumpulkan data yang diperoleh dari situs $\quad$ http://proper.menlhk.go.id, http://www.idx.co.id, dan website masingmasing perusahaan.

\section{Data dan Teknik Pengumpulan}

Sumber data yang digunakan dalam penelitian ini merupakan data sekunder, yaitu data yang dikumpulkan peneliti yang diterbitkan dalam jurnal statistik dan lainnya, serta informasi yang tersedia dari sumber publikasi atau nonpublikasi baik di dalam atau luar organisasi yang dapat berguna bagi peneliti (Sekaran, 2011: 245). Data yang dibutuhkan berupa laporan 
JURNAL NOMINAL / VOLUME VIII NOMOR 1 / TAHUN 2019

PROPER, laporan keuangan, dan laporan tahunan, serta untuk tambahan informasi juga digunakan laporan keberlanjutan.

Teknik analisis data dalam penelitian ini adalah regresi linier sederhana, analisis jalur, dan uji Sobel. Regresi linier sederhana digunakan untuk mengetahui pengaruh satu variabel independen dengan satu variabel dependen, yaitu untuk menguji hipotesis pertama, kedua, ketiga, dan keempat. Sedangkan analisis jalur hanya digunakan untuk menentukan pola hubungan antara tiga atau lebih variabel dan tidak dapat digunakan untuk mengkonfirmasi atau menolak hipotesis kausalitas imajiner (Ghozali, 2011: 249), sehingga untuk melakukan pembuktian pada hipotesis digunakan uji Sobel untuk menentukan pengaruh mediasi yang terjadi bersifat signifikan atau tidak, teknik ini untuk menguji hipotesis kelima, keenam, dan ketujuh

\section{HASIL PENELITIAN DAN} PEMBAHASAN

\section{Statistik Deskriptif}

Analisis data statistik deskriptif yang disajikan dalam penelitian ini meliputi Minimal, Maksimal, Mean, dan Standar Deviasi (SD). Berikut adalah hasil analisis statistik deskriptif dari data penelitian:

\begin{tabular}{lrrrr}
\hline Var & Min. & Maks. & Mean & SD \\
\hline KK & 0,0007 & 0,4317 & 0,0834 & 0,0800 \\
& 6 & 0 & 8 & 3 \\
\hline KL & 2,00 & 5,00 & 3,02 & 0,50 \\
\hline BL & 0,0002 & 1,1440 & 0,0678 & 0,1969 \\
& 9 & 8 & 9 & 1 \\
\hline UkP & 26,67 & 33,20 & 29,38 & 1,50 \\
\hline CSR & 0,16 & 0,57 & 0,32 & 0,09
\end{tabular}

Tabel 1. Hasil Analisis Deskriptif (Sumber: Data Sekunder Diolah)

1) Uji Asumsi Klasik

Pengujian asumsi klasik menunjukkan tidak lolosnya salah satu uji asumsi yaitu uji normalitas. Oleh karena itu, dilakukan transform pada data.

2) Uji Normalitas

\begin{tabular}{lrr}
\hline Dependen & $\begin{array}{r}\text { Kolmogrov- } \\
\text { Smirnov }\end{array}$ & $\begin{array}{r}\text { Asymp-Sig. } \\
\text { (2-tailed })\end{array}$ \\
\hline CSR & 0,72 & 0,200 \\
\hline KK & 0,82 & 0,115 \\
\hline
\end{tabular}

Tabel 2. Hasil Uji Normalitas (Sumber:

Data Sekunder Diolah)

Berdasarkan hasil uji Normalitas di atas, nilai Asymp. Sig. (2-tailed) sudah lebih besar dari 0,05 maka dapat disimpulkan bahwa data berdistribusi normal. 
3) Uji Multikolinearitas

\begin{tabular}{llrr}
\hline Dependen & \multicolumn{1}{c}{$\begin{array}{c}\text { Indepen- } \\
\text { den }\end{array}$} & $\begin{array}{c}\text { Nilai } \\
\text { Tolerance }\end{array}$ & $\begin{array}{c}\text { Nilai } \\
\text { VIF }\end{array}$ \\
\hline CSR & KL & 0,82 & 1,22 \\
\cline { 2 - 4 } & BL & 0,94 & 1,07 \\
\cline { 2 - 4 } & UkP & 0,81 & 1,23 \\
\hline KK & KL & 0,62 & 1,62 \\
\cline { 2 - 4 } & BL & 0,92 & 1,08 \\
\cline { 2 - 4 } & UkP & 0,73 & 1,38 \\
\cline { 2 - 4 } & CSR & 0,58 & 1,74
\end{tabular}

Tabel 3. Hasil Uji Multikolinearitas Dependen CSR (Sumber: Data Sekunder Diolah)

Tabel di atas menunjukkan bahwa semua variabel independen mempunyai nilai Tolerance $\geq 0,10$ dan Variance Inflation Factor (VIF) $\leq 10$. Jadi, dapat disimpulkan bahwa pada penelitian ini tidak ada multikolonieritas antar variabel dalam model regresi.

4) Uji Autokorelasi

\begin{tabular}{lr}
\hline \multicolumn{1}{c}{ Dependen } & \multicolumn{1}{c}{ Durbin-Watson } \\
\hline CSR & 1,879 \\
\hline KK & 2,085
\end{tabular}

Tabel 4. Hasil Uji Autokorelasi (Sumber: Data Sekunder Diolah)

Berdasarkan hasil pengujian diperoleh nilai Durbin-Watson, kemudian dibandingkan dengan nilai dU dan $4-\mathrm{dU}$ dan dilakukan pengambilan keputusan dengan ketentuan nilai DW harus lebih besar dari du dan lebih kecil dari 4-dU. Adapun hasilnya yaitu $1,7335<1,879<$ 2,2665 serta $1,7560<2,085<2,2440$. Hal ini dapat disimpulkan bahwa tidak terjadi autokorelasi antara variabel independen sehingga layak digunakan.

5) Uji Heteroskedastisitas

\begin{tabular}{lll}
\hline Dependen & \multicolumn{1}{c}{ Independen } & \multicolumn{1}{c}{ Sig. } \\
\hline CSR & KL & 0,121 \\
\cline { 2 - 3 } & BL & 0,360 \\
\cline { 2 - 3 } & UkP & 0,408 \\
\hline KK & KL & 0,783 \\
\cline { 2 - 3 } & BL & 0,058 \\
\cline { 2 - 3 } & UkP & 0,423 \\
\cline { 2 - 3 } & CSR & 0,824
\end{tabular}

Tabel 5. Hasil Uji Heteroskedastisitas (Sumber: Data Sekunder Diolah)

Tabel di atas menunjukkan bahwa tidak ada satu pun variabel independen yang mempunyai nilai signifikansi lebih dari 0,05. Jadi, dapat disimpulkan bahwa model regresi pada penelitian ini tidak terjadi heteroskedastisitas.

6) Uji Linieritas

\begin{tabular}{lr}
\hline \multicolumn{1}{c}{ Dependen } & $\boldsymbol{R}$ Square \\
\hline CSR & 0,425 \\
\hline KK & 0,580 \\
\hline
\end{tabular}

Tabel 6. Hasil Uji Linieritas (Sumber: Data Sekunder Diolah)

Diketahui nilai R2 (R Square) sebesar 0,425 dan 0,580 dengan jumlah $\mathrm{n}=97$, maka besarnya nilai $\mathrm{c}^{2}$ hitung $=97 \mathrm{x} 0,425$ $=41,225$ serta $c^{2}$ hitung $=97 \times 0,580=$ 56,26 . Nilai ini dibandingkan dengan $\mathrm{c}^{2}$ tabel $\mathrm{df}=97$ dan tingkat signifikansi 0,05 didapat nilai $\mathrm{c}^{2}$ tabel $=120,990$. Oleh karena nilai $c^{2}$ hitung lebih kecil dari $c^{2}$ 
tabel maka dapat disimpulkan bahwa model yang benar adalah model linier.

\section{Uji Hipotesis}

\section{Pengaruh Kinerja Lingkungan}

\section{Terhadap Kinerja Keuangan}

H1: Kinerja lingkungan berpengaruh positif terhadap kinerja keuangan.

Tabel 7. Hasil Uji Hipotesis 1

\begin{tabular}{lll}
\hline Konstanta & $=\mathbf{- 3 , 7 5 8}$ & \\
\hline Koef. Regresi & $=\mathbf{0 , 7 1 0}$ & \\
\hline Signifikansi & $=\mathbf{0 , 3 3 5}$ & \\
\hline t hitung $=\mathbf{0 , 9 6 9}$ & $\mathrm{r}=0,99$ \\
\hline t tabel $=\mathbf{1 , 6 6 0 7}$ & $\mathrm{r}^{2}=0,010$
\end{tabular}

Sumber: Data Sekunder Diolah

Berdasarkan hasil uji hipotesis diperoleh nilai t hitung sebesar 0,969 lebih kecil dari nilai t tabel $(1,6607)$, dengan signifikansi $0,335(>0,05)$. Hal ini berarti bahwa tidak ada pengaruh signifikan yang terjadi pada kinerja lingkungan ke kinerja keuangan, sehingga hipotesis pertama ditolak.

Dari 97 data yang diolah peneliti ratarata perusahaan memperoleh peringkat biru yang artinya perusahaan melakukan upaya pengelolaan lingkungan hanya sesuai dengan yang diatur oleh undang-undang. Namun, dari hasil kinerja lingkungan yang bisa dibilang cukup tersebut belum bisa serta-merta menjamin hasil kinerja keuangan yang baik pula. Hal ini mengindikasikan bahwa stakeholder ataupun masyarakat merasa bahwa hasil tersebut tidak sesuai dengan ekspektasi. Mereka berharap bahwa perusahaan dapat melakukan pengelolaan lingkungan lebih dari yang dipersyaratkan undang-undang, seperti dapat memanfaatkan sumber daya secara efisien serta melaksanakan 3R (Reuse, Reduce, Recycle).

Oleh karena hal itu hasil kinerja lingkungan dari peringkat PROPER belum mampu menarik minat stakeholder untuk menanamkan modalnya di perusahaan. Padahal dengan adanya asupan modal dapat digunakan perusahaan baik untuk kegiatan operasional maupun produksi yang dimaksudkan untuk peningkatan laba.

Disisi lain, untuk mendapatkan ranking warna yang tinggi dalam PROPER tentu banyak persyaratan yang harus dipenuhi perusahaan. Untuk merealisasikan persyaratan yang banyak, perusahaan tentu juga harus mengucurkan sejumlah dana yang banyak pula. Adanya pengeluaran dana tersebut bagi perusahaan merupakan biaya. Dengan demikian, kegiatan PROPER yang diikuti perusahaan juga memerlukan dana yang bisa dianggap biaya oleh perusahaan.

Hasil uji hipotesis pertama ini sejalan dengan penelitian yang dilakukan oleh Rakhiemah \& Agustia (2009), Pujiasih (2013), dan Angela (2015) namun bertentangan dengan penelitian Al- 


\section{JURNAL NOMINAL / VOLUME VIII NOMOR 1 / TAHUN 2019}

Tuwaijri et al. (2004), Fitriani (2013), dan Tunggal \& Fachrurrozie (2014).

\section{Pengaruh Biaya Lingkungan Terhadap} Kinerja Keuangan

$\mathrm{H} 2$ : Biaya lingkungan berpengaruh positif terhadap kinerja keuangan.

\begin{tabular}{lll}
\hline Konstanta & $=\mathbf{- 4 , 3 7 3}$ & \\
\hline Koef. Regresi & $=\mathbf{- 0 , 3 1 8}$ & \\
\hline Signifikansi $=\mathbf{0 , 0 0 0}$ & \\
\hline t hitung $=\mathbf{- 5 , 3 0 8}$ & $\mathrm{r}=0,99$ \\
\hline t tabel $=\mathbf{- 1 , 6 6 0 7}$ & $\mathrm{r}^{2}=0,010$
\end{tabular}

Tabel 8. Hasil Uji Hipotesis 2 (Sumber: Data Sekunder Diolah)

Pengujian hipotesis kedua menunjukkan nilai $\mathrm{t}$ hitung sebesar $-5,308$ lebih kecil dari nilai t tabel $(-1,6607)$, dengan signifikansi 0,000 $(<0,05)$. Hal ini berarti bahwa pengaruh yang terjadi pada biaya lingkungan ke kinerja keuangan adalah negatif signifikan, sehingga hipotesis kedua dalam penelitian ini ditolak.

Biaya lingkungan yang diharapkan dapat menjadi investasi jangka panjang ternyata belum bisa dibuktikan dalam penelitian ini. Hal ini dapat dilihat dari hasil penelitian ada pengaruh negatif yang signifikan. Hal tersebut bisa terjadi karena biaya lingkungan yang dikeluarkan perusahaan diindikasikan menjadi tambahan pengeluaran oleh perusahaan. Fitriani (2013) menyatakan terkadang perusahaan mengabaikan biaya lingkungan yang dikeluarkan oleh perusahaan, hingga berakibat tidak terlihat di laporan keuangan tahunan perusahaan. Dampaknya terhadap laporan keuangan akan memburuk dikarenakan membengkaknya biaya lingkungan yang dikeluarkan.

Di samping itu biaya lingkungan yang dikeluarkan perusahaan biasanya juga dibebankan pada harga produk. Artinya jika biaya lingkungan cukup banyak besar kemungkinan harga dari produk yang perusahaan juga akan mengalami kenaikan. Tentu harga produk yang semakin mahal akan tidak diterima dan memberatkan masyarakat, hingga pada akhirnya terjadi penurunan pendapatan.

Data biaya lingkungan yang ditemukan penulis dalam penelitian ini pun mayoritas dalam kategori rendah. Terlebih persentase biaya lingkungan yang berkategori rendah sebesar $95,88 \%$, yang mana persentase tersebut terhitung sangat besar. Kemungkinan ini lah yang membuat biaya lingkungan berpengaruh negatif pada kinerja keuangan dalam penelitian ini.

Hasil uji hipotesis ini tidak sejalan dengan penelitian Fitriani (2013) dan Camilia (2016) yang tidak menemukan hubungan antara biaya lingkungan dengan kinerja keuangan. Di sisi lain uji hipotesis ini juga bertentangan dengan penelitian $\mathrm{Al}$ Sharairi (2005) yang menyatakan terdapat pengaruh positif antara biaya lingkungan dengan kinerja keuangan. 
Pengaruh Ukuran Perusahaan Terhadap Kinerja Keuangan

H3: Ukuran perusahaan berpengaruh positif terhadap kinerja keuangan.

\begin{tabular}{lll}
\hline Konstanta & $=\mathbf{- 8 , 6 3 1}$ & \\
\hline Koef. Regresi & $=\mathbf{0 , 1 9 2}$ & \\
\hline Signifikansi & $=\mathbf{0 , 0 1 5}$ & \\
\hline $\mathbf{t}$ hitung $=\mathbf{2 , 4 7 0}$ & $\mathrm{r}=0,246$ \\
\hline $\mathbf{t}$ tabel $=\mathbf{1 , 6 6 0 7}$ & $\mathrm{r}^{2}=0,060$ \\
\hline
\end{tabular}

Tabel 9. Hasil uji hipotesis 3 (Sumber: Data Sekunder Diolah)

Pengujian hipotesis ketiga menunjukkan nilai t hitung sebesar 2,470 lebih besar dari nilai $\mathrm{t}$ tabel $(1,6607)$, dengan signifikansi 0,015 $(<0,05)$. Hal ini berarti bahwa pengaruh yang terjadi pada ukuran perusahaan ke kinerja keuangan ini adalah positif signifikan, sehingga hipotesis ketiga dalam penelitian ini dapat diterima.

Penilaian ukuran perusahaan dalam penelitian ini menggunakan total aset. Akbar (2013) mengungkapkan bahwa semakin besar total aktiva suatu perusahaan, maka semakin besar kemampuan perusahaan tersebut dalam menghasilkan laba. Peningkatan laba merupakan indikasi meningkatkan kinerja keuangan milik perusahaan.

Menurut Sugiono \& Christiawan (2013) perusahaan yang berukuran besar memiliki akses lebih untuk mendapat sumber pendanaan dari luar, karena perusahaan dengan ukuran besar memiliki kesempatan lebih besar untuk memenangkan persaingan atau bertahan dalam industri. Dengan kata lain investor lebih tertarik untuk menanamkan modalnya di perusahaan yang berukuran besar. Adanya tambahan modal dari investor dapat digunakan perusahaan baik untuk operasional ataupun produksi demi kemajuan perusahaan hingga akhirnya kinerja keuangan perusahaan dapat menjadi lebih baik.

Hasil uji hipotesis ketiga ini sejalan dengan penelitian yang dilakukan oleh Agrestya (2011) dan Akbar (2013). Namun, bertentangan dengan penelitian Fitriani (2013) dan Rifan (2015) yang tidak menemukan adanya hubungan antara ukuran perusahaan dengan kinerja keuangan.

\section{Pengaruh Corporate Social Responsibility}

\section{Terhadap Kinerja Keuangan}

H4: Corporate Social Responsibility berpengaruh positif terhadap kinerja keuangan.

\begin{tabular}{lll}
\hline Konstanta & $=\mathbf{- 5 , 3 4 2}$ & \\
\hline Koef. Regresi & $=\mathbf{7 , 4 6 2}$ & \\
\hline Signifikansi & $=\mathbf{0 , 0 0 0}$ & \\
\hline t hitung $=\mathbf{7 , 0 0 3}$ & & $\mathrm{r}=0,584$ \\
\hline $\mathbf{t}$ tabel $=\mathbf{1 , 6 6 0 7}$ & $\mathrm{r}^{2}=0,340$ \\
\hline
\end{tabular}

Tabel 10. Hasil Uji Hipotesis 4 (Sumber: Data Sekunder Diolah)

Pengujian hipotesis keempat menunjukkan nilai t hitung sebesar 7,003 lebih besar dari nilai t tabel $(1,6607)$, 


\section{JURNAL NOMINAL / VOLUME VIII NOMOR 1 / TAHUN 2019}

dengan signifikansi $0,000(<0,05)$. Hal ini berarti bahwa pengaruh yang terjadi pada Corporate Social Responsibility ke kinerja keuangan adalah positif signifikan, sehingga hipotesis keempat dalam penelitian ini dapat diterima.

Pelaksanaan Corporate Social Responsibility yang baik sudah dilihat oleh investor sebagai good news. Good news ini dapat mempengaruhi keputusan investor dalam berinvestasi. Lebih lanjut perusahaan akan mendapat respon positif dari para investor tersebut untuk mendapatkan tambahan modal yang dapat digunakan untuk menunjang kegiatan operasional serta keuangan perusahaan.

Selain itu pelaksanaan Corporate Social Responsibility juga menunjukkan kepedulian perusahaan pada kualitas produk yang dihasilkan, hal ini dapat diketahui karena salah satu kegiatan Corporate Social Responsibility juga mencakup tanggung jawab pada produk. Kepedulian perusahaan pada hal-hal tersebut dapat meningkatkan citra dan nama baik perusahaan. Jika citra perusahaan semakin baik maka loyalitas konsumen dan para stakeholder akan semakin tinggi pula (Angela 2015). Seiring meningkatnya loyalitas dalam waktu lama, maka penjualan perusahaan akan semakin membaik, dan pada akhirnya dengan melaksanakan CSR tingkat profitabilitas perusahaan juga meningkat (Satyo, 2005 dalam Rahmawati, 2012). Dengan adanya peningkatan profitabilitas, maka kinerja keuangan perusahaan akan meningkat pula.

Hasil uji hipotesis keempat ini sejalan dengan penelitian yang dilakukan oleh AlTuwaijri et al. (2004), Pujiasih (2013), dan Rifan (2015) namun bertentangan dengan penelitian Rakhiemah \& Agustia (2009), Tunggal \& Fachrurrozie (2014), serta Angela (2015).

Pengaruh Kinerja Lingkungan Terhadap Kinerja Keuangan Dengan Dimediasi Corporate Social Responsibility

H5: Kinerja lingkungan berpengaruh terhadap kinerja keuangan dengan dimediasi Corporate Social Responsibility.

\begin{tabular}{ll}
\hline Pengaruh langsung & $=\mathbf{p} \mathbf{1}$ \\
& $=\mathbf{- 2 , 6 0 0}$ \\
\hline Pengaruh tidak & $=\mathrm{p} 2 \times \mathrm{p} 3$ \\
langsung & $=0,326 \times 10,154$ \\
& $=3,310$ \\
\hline Indirrect Effect & $=0,625$ \\
(Sp2p3) & \\
\hline t hitung & $=5,295$
\end{tabular}

Tabel 11. Hasil Uji Hipotesis 5 (Sumber: Data Sekunder Diolah)

Pengaruh tak langsung sebesar 3,310 lebih besar dari pengaruh langsung sehingga Corporate Social Responsibility dapat memperkuat pengaruh kinerja lingkungan terhadap kinerja keuangan. Dari uji Sobel juga diketahui nilai t hitung (nilai pengaruh tidak langsung dibagi nilai 
Sp2p3) sebesar 5,295 lebih besar dari nilai $\mathrm{t}$ tabel dengan tingkat signifikansi 5\% yaitu 1,6607, maka dapat disimpulkan terdapat pengaruh mediasi dan hipotesis kelima dapat diterima

Kinerja lingkungan tidak dapat lepas dengan adanya Corporate Social Responsibility. Hal ini dikarenakan salah satu pelaksanakan Corporate Social Responsibility yang diungkapkan adalah kinerja lingkungan. Corporate Social Responsibility yang biasanya dilaporkan di laporan tahunan sering menjadi perhatian stakeholder dalam pengambilan keputusan. Kegiatan Corporate Social Responsibility ini mampu meningkatkan legitimasi dari banyak pihak sehingga mampu meningkatkan image positif perusahaan yang akan berdampak pada kelangsungan perusahaan (Pujiasih, 2013). Adanya image positif yang diperoleh perusahaan tentu akan mendapat pandangan yang positif dari para stakeholder. Adanya respon positif ini pada akhirnya akan meningkatkan kinerja keuangan perusahaan baik dari peningkatan penjualan dan peningkatan laba ataupun mendapatkan tambahan modal.

Hasil uji hipotesis kelima ini sejalan dengan penelitian yang dilakukan oleh Rakhiemah \& Agustia (2009), Rahmawati (2012) dan Pujiasih (2013) namun tidak sejalan dengan penelitian yang dilakukan Tunggal \& Fachrurrozie (2014) serta Angela (2015).
Pengaruh Biaya Lingkungan Terhadap Kinerja Keuangan Dengan Dimediasi Corporate Social Responsibility

H6: Biaya lingkungan berpengaruh terhadap kinerja keuangan dengan dimediasi Corporate Social Responsibility.

\begin{tabular}{ll}
\hline Pengaruh langsung & $=\mathbf{p} 1$ \\
& $=\mathbf{- 0 , 2 9 0}$ \\
\hline Pengaruh tidak & $=\mathrm{p} 2 \times \mathrm{p} 3$ \\
langsung & $=-0,004 \times 7,039$ \\
& $=-0,028$ \\
\hline Indirrect Effect & $=0,357$
\end{tabular}

(Sp2p3)

t hitung $=-0,789$

Tabel 12. Hasil Uji Hipotesis 6 (Sumber: Data Sekunder Diolah)

Pengaruh tak langsung sebesar $-0,028$ lebih besar dari pengaruh langsung. Namun, dari uji Sobel diketahui nilai t hitung (nilai pengaruh tidak langsung dibagi nilai Sp2p3) yaitu -0,789 lebih kecil dari nilai t tabel dengan tingkat signifikansi $5 \%$ yaitu 1,6607, maka dapat disimpulkan tidak terdapat pengaruh mediasi dan hipotesis keenam ditolak.

Besarnya biaya lingkungan yang dikeluarkan ternyata tidak menjamin banyaknya kegiatan Corporate Social Responsibility yang dilakukan perusahaan, terlebih data biaya lingkungan dalam penelitian ini mayoritas berkategori rendah.

Kualitas kegiatan Corporate Social Responsibility juga tidak dapat dilihat dari jumlah biaya lingkungan. Padahal 
JURNAL NOMINAL / VOLUME VIII NOMOR 1 / TAHUN 2019

Corporate Social Responsibility yang baik bisa menjadi good news untuk para stakeholder dan lebih lanjut akan direspon positif oleh stakeholder yang dapat memberikan keuntungan bagi perusahaan terlebih dari segi finansial. Dengan tidak adanya pengaruh yang berarti dari biaya lingkungan terhadap Corporate Social Responsibility ini membuktikan bahwa pengaruh tidak langsung biaya lingkungan terhadap kinerja keuangan melalui Corporate Social Responsibility ini tidaklah kuat.

Hasil uji hipotesis keenam ini bertentangan dengan penelitian yang dilakukan oleh Tunggal \& Fachrurrozie (2014) yang menyatakan bahwa terdapat pengaruh positif yang signifkan antara biaya lingkungan terhadap kinerja keuangan dengan dimediasi Corporate Social Responsibility.

\section{Pengaruh Ukuran Perusahaan}

Terhadap Kinerja Keuangan Dengan

\section{Dimediasi Corporate Social \\ Responsibility}

H7: Ukuran perusahaan berpengaruh terhadap kinerja keuangan dengan dimediasi Corporate Social Responsibility.

\begin{tabular}{ll}
\hline Pengaruh langsung & $=\mathbf{p 1}$ \\
& $=\mathbf{- 0 , 0 3 7}$ \\
\hline Pengaruh tidak & $=\mathrm{p} 2 \times \mathrm{p} 3$ \\
langsung & $=0,030 \times 7,758$ \\
& $=0,233$ \\
\hline Indirrect Effect & $=0,0537$ \\
$(\mathbf{S p 2 p 3})$ & \\
\hline $\mathbf{t}$ hitung & $=4,339$
\end{tabular}

Tabel 13. Hasil Uji Hipotesis 7 (Sumber: Data Sekunder Diolah)

Pengaruh tak langsung sebesar 0,233 lebih besar dari pengaruh langsung sehingga Corporate Social Responsibility dapat memperkuat pengaruh ukuran perusahaan terhadap kinerja keuangan. Dari uji Sobel juga diketahui nilai t hitung (nilai pengaruh tidak langsung dibagi nilai Sp2p3) sebesar 4,339 lebih besar dari nilai $\mathrm{t}$ tabel dengan tingkat signifikansi 5\% yaitu 1,6607, maka dapat disimpulkan terdapat pengaruh mediasi dan hipotesis ketujuh dapat diterima

Diterimanya Corporate Social Responsibility sebagai mediasi antara pengaruh ukuran perusahaan ke kinerja keuangan ini membuktikan bahwa semakin banyak jumlah aset (ukuran perusahaan) maka akan semakin banyak pengungkapan CSR yang akan dilakukan perusahaan (Nur \& Priantinah, 2012). Adanya Corporate Social Responsibility sebagai variabel mediasi juga memperkuat pengaruh yang sudah ada. Hal ini dikarenakan selain perusahaan yang besar dianggap relatif stabil dan mampu menghasilkan laba yang 


\section{JURNAL NOMINAL / VOLUME VIII NOMOR 1 / TAHUN 2019}

tinggi (Aprianingsih, 2016), perusahaan besar juga akan mendapatkan perhatian lebih oleh para stakeholder (Yao et al, 2011). Dengan demikian stakeholder akan melihat bahwa perusahaan tersebut tak hanya perusahaan yang menarik dari segi finansial tetapi dari segi sosial dan lingkungan perusahaan juga memberikan kepeduliannya. Adanya pandangan yang positif dari stakeholder ini tentu akan memberikan keuntungan bagi perusahaan yang akhirnya kinerja keuangan perusahaan juga akan meningkat.

\section{SIMPULAN DAN SARAN}

\section{Simpulan}

Kinerja lingkungan tidak berpengaruh terhadap kinerja keuangan, hal ini membuktikan bahwa kinerja lingkungan tidak mampu mempengaruhi kinerja keuangan suatu perusahaan. Biaya lingkungan berpengaruh negatif signifikan terhadap kinerja keuangan, artinya semakin banyak biaya lingkungan yang dikeluarkan maka kinerja keuangan suatu perusahaan akan mengalami penurunan. Ukuran perusahaan berpengaruh positif signifikan terhadap kinerja keuangan, hal ini membuktikan bahwa semakin besar ukuran suatu perusahaan maka akan semakin meningkat pula kinerja keuangan perusahaan. Corporate Social Responsibility berpengaruh positif signifikan terhadap kinerja keuangan, artinya semakin banyak kegiatan Corporate Social Responsibility yang dilaksanakan perusahaan maka akan semakin meningkat pula kinerja keuangan perusahaan. Corporate Social Responsibility sebagai variabel intervening mampu memediasi pengaruh pada kinerja lingkungan ke kinerja keuangan. Corporate Social Responsibility sebagai variabel intervening tidak mampu untuk memediasi pengaruh pada biaya lingkungan ke kinerja keuangan. Dan terakhir, Corporate Social Responsibility sebagai variabel intervening mampu untuk memediasi pengaruh pada ukuran perusahaan ke kinerja keuangan.

\section{Saran}

Perusahaan sebaiknya bisa lebih meningkatkan kegiatan dan kualitas Corporate Social Responsibility, karena kegiatan ini terbukti bisa memberikan manfaat finansial perusahaan. Perusahaan juga diharapkan dapat membuat kebijakan untuk menunjang dan memenuhi Hak Asasi Manusia para karyawan, karena data penelitian ini menunjukkan kegiatan atau pengungkapan Corporate Social Responsibility yang berkaitan dengan Hak Asasi Manusia masihlah rendah. Pengungkapan Corporate Social Responsibility dalam laporan tahunan sebaiknya mengacu pada Global Reporting Initiative sesuai dengan standar internasional yang berlaku. Perusahaan juga diharapkan dapat meningkatkan 


\section{JURNAL NOMINAL / VOLUME VIII NOMOR 1 / TAHUN 2019}

manajemen lingkungan dengan memfokuskan pada prevention atau pencegahan, karena data yang diperoleh penulis menunjukkan ranking PROPER perusahaan sebagian besar memperoleh ranking biru bahkan ada perusahaan yang masih memperoleh peringkat merah

Pemerintah dalam hal ini Kementrian Lingkungan Hidup sebaiknya menetapkan peraturan yang lebih ketat akan pelaksanaan kegiatan perusahaan yang berkaitan dengan pengelolaan lingkungan. Selain itu pemerintah sebaiknya juga gencar untuk melakukan sosialisasi mengenai peraturan pengelolaan lingkungan pada perusahaan-perusahaan, sehingga informasi dapat tersalurkan secara maksimal serta meningkatkan pemahaman perusahaan. Lebih lanjut juga diadakan sanksi dan denda terkait pelanggaran atas pencemaran lingkungan, sehingga dapat meningkatkan ketaatan perusahaan atas pengelolaan lingkungan serta juga dapat memberikan efek jera dari perusahaan yang melakukan pencemaran.

Untuk penelitian selanjutnya sebaiknya menambah periode sampel menjadi minimal 5 tahun periode. Cakupan perusahaan bisa diperluas, sehingga kesimpulan dari hasil penelitian dapat digeneralisasi dengan lebih baik. Untuk penilaian Corporate Social Responsibility sebaiknya tidak hanya menggunakan laporan tahunan saja tetapi juga menggunakan laporan keberlanjutan untuk menghindari penilaian yang subjektif. Variabel lain seperti Leverage dan Good Corporate Governance juga dapat digunakan untuk melihat pengaruh ke kinerja keuangan baik dimediasi Corporate Social Responsibility ataupun tanpa mediator. Selain itu penggunaan Corporate Social Responsibility untuk memediasi pengaruh pengungkapan CSR di media terhadap kinerja keuangan juga dapat diselidiki lebih lanjut.

\section{DAFTAR PUSTAKA}

Agrestya, W. (2011). "Analisis Pengaruh Ukuran Perusahaan dan Struktur Modal. Terhadap Kinerja Keuangan Pada Perusahaan Manufaktur yang Terdaftar di Bursa Efek Indonesia”. Skripsi. Universitas Diponegoro.

Akbar, D.A. (2013). "Analisis Pengaruh Ukuran Perusahaan, Kecukupan Modal, Kualitas Aktiva Produktif (KAP) dan Likuiditas Terhadap Kinerja Keuangan". Jurnal Ilmiah STIE MDP, 3 (1), 66-82.

Al Sharairi, J.A. (2005). "The Impact Of Environmental Costs on The Competitive Advantage of Pharmaceutical Companies in Jordan". Middle Eastern Finance and Economics. ISSN: 1450-2889 Issue 15.

Al-Tuwaijri, S.A., Christensen, T.E., \& Hughes, K.E. (2004). "The Relations Among Environmental Disclosure, Environmental Performance, and Economic Performance: A Simultaneous Equations Approach". Accounting, Organizations and Society, 29, 44771. 
Angela. (2015). "Pengaruh Kinerja Lingkungan Terhadap Kinerja Finansial dengan Pengungkapan Corporate Social Responsibility (CSR) Sebagai Variabel Intervening". Skripsi. Universitas Sanata Dharma.

Bukti Newmont Melakukan Pencemaran Semakin Terang. Diakses dari https://news.liputan6.com, pada 3 Januari 2018.

Camilia, I. (2016). "Pengaruh Kinerja Lingkungan dan Biaya Lingkungan Terhadap Kinerja Keuangan Perusahaan Manufaktur". Skripsi. Sekolah Tinggi Ilmu Ekonomi Perbanas.

Fajriana, A. (2016). "Pengaruh Corporate Social Responsibility (CSR), Keputusan Investasi, dan Struktur Modal Terhadap Nilai Perusahaan Dengan Kepemilikan Manajerial Sebagai Variabel Pemoderasi”. Skripsi. Universitas Negeri Yogyakarta.

Fitriani, A. (2012). "Pengaruh Kinerja Lingkungan dan Biaya Lingkungan Terhadap Kinerja Keuangan Pada BUMN". Jurnal Ilmu Manajemen, 1(1), 137-148.

Ghozali, I. (2011). Aplikasi Analisis Multivariate dengan Program IMB SPSS 19. Semarang: Badan Penerbit Universitas Diponegoro.

Hadi, N. (2011). Corporate Social Responsibility. Yogyakarta: Graha Ilmu

Hastawati, R.R., \& Sarsiti. (2016). "Pengaruh Kinerja Lingkungan dan Corporate Social Responsibility (CSR) Terhadap Kinerja Keuangan Pada Perusahaan Manufaktur yang
Terdaftar di Bursa Efek Indonesia Tahun 2011-2013". Jurnal Penelitian dan Kajian Ilmiah Universitas Surakarta, 14 (4), 4959.

Jayati, S.E. (2016). "Pengaruh Intellectual Capital Terhadap Kinerja Keuangan Perusahaan Perdagangan Jasa yang Terdaftar di Bursa Efek Indonesia”. Skripsi. Universitas Negeri Yogyakarta.

Kementrian Lingkungan Hidup. "Program Penilaian Peringkat Kinerja

Perusahaan dalam Pengelolaan

Lingkungan Hidup (PROPER)”.

Diakses melalui

http://proper.menlhk.go.id pada tanggal 5 Januari 2018.

Khusuma, E. (2016). "Menjelang 10 Tahun Lumpur Lapindo, Ini Dia 10 Fakta Terkait "Perbaikan Signifikan" yang Terjadi". Diakses dari https://news.idntimes.com, pada 3 Januari 2018.

Nur, M. \& Priantinah, D. (2012). “Analisis Faktor-Faktor yang Mempengaruhi Pengungkapan Corporate Social Responsibility di Indonesia (Studi Empiris Pada Perusahaan Berkategori High Profile yang Listing di Bursa Efek Indonesia)". Jurnal Nominal, 1 (1), 22-34.

Margono, S. (1997). Metodologi Penelitian Pendidikan Komponen MKDK. Jakarta: Renika Cipta.

Pujiasih. (2013). "Pengaruh Kinerja Lingkungan Terhadap Kinerja Keuangan dengan Corporate Social Responsibility (CSR) Sebagai Variabel Intervening". Skripsi. Universitas Negeri Semarang.

Rahmawati, A. (2012). "Pengaruh Kinerja Lingkungan Terhadap Corporate 

"Pengaruh Kinerja Lingkungan Terhadap Corporate Social Responsibility (CSR) Disclosure dan Kinerja Finansial Perusahaan Manufaktur yang Terdaftar di Bursa Efek Indonesia". Simposium Nasional Akuntansi XII, (4-6 November) 2009, Palembang.

Rifan, D.F. (2015). "Pengaruh Pengungkapan Corporate Social. Responbility dan Ukuran Perusahaan Terhadap Kinerja Keuangan”. Skripsi. Universitas Lampung.

Sekaran, U. (2011). Research Methods For Business. Jakarta: Salemba Empat.

Sugiono, L.P., \& Christiawan Y.J. (2013). "Analisa Faktor yang Mempengaruhi Likuiditas Pada Industri Ritel yang Terdaftar Pada Bursa Efek Indonesia Tahun 20072012". Business Accounting Review, 1 (2), 298-305.

Sugiyono. (2011). Metode Penelitian Administrasi. Bandung: Alfabeta.

Susanto, A.B. (2009). Reputation Driven Corporate Social Responsibility Pendekatan Strategic Management dalam CSR. Jakarta: Esensi Erlangga.

Tunggal W.S.P., \& Fachrurrozie. (2014). "Pengaruh Environmental Performance, Environmental Cost dan CSR Disclosure Terhadap Financial Performance". Accounting Analysis Journal, 3 (3), 310-320.

\section{JURNAL NOMINAL / VOLUME VIII NOMOR 1 / TAHUN 2019}
Financial Performance dengan Corporate Social Responsibility Disclosure Sebagai Variabel Intervening". Skripsi. Universitas Diponegoro.
Rakhiemah, A.N., \& Agustia D. (2009).

\author{
Yao, S., Wang, J., \& Song, L. (2011). \\ China Policy Institute, 1-30.
}
"Determinants of Social
Responsibility Disclosure by
Chinese Firms". Discussion Paper.
The University of Nottingham,
"Determinants of Social
Chinese Firms". Discussion Paper.
The University of Nottingham,
"Determinants of Social
Chinese Firms". Discussion Paper.
The University of Nottingham,
"Determinants of Social
Chinese Firms". Discussion Paper.
The University of Nottingham,

